\title{
What shapes the governance of the dairy value chain in Vietnam? Insights from Ba-Vì milkshed (Hanoi)
}

Mai-Huong Nguyen ${ }^{1}$, Guillaume Duteurtre ${ }^{2}$, Paule Moustier ${ }^{3}$

\begin{abstract}
Vietnam has experienced a rapid growth in the dairy sector since the early 2000s. However, the organization of the sector is said to be inequitable and its motivational mechanisms are not sufficient to ensure the development of smallholder farmers. To assess smallholders' prospects in the upgrading process of the whole dairy sector, we conducted a study in Ba-Vì district, the largest "milkshed" in the Red River Delta, which has undergone a remarkable transition from state-owned concentrated production to smallholder farms. The study focuses on value chain governance and upgrading strategies. The local dairy value chain is dominated by smallholders and characterized by contractual relations between private milk collectors and industrial, semi-industrial, and cottage processors. The local chain is featured by a mixed relational-captive governance pattern. Relational governance characterizes the two sub-channels in which small-scale industries operate. Captive governance describes the leading role of a medium-size dairy firm that has invested in UHT processing facilities and benefited from support from the local government. The strong role of public authorities and some challenges for chain upgrading are discussed.
\end{abstract}

Keywords: dairy sector, value chain governance, livestock development, Vietnam

\section{RESUMEN}

Vietnam ha tenido un crecimiento rápido en el sector lechero desde los primeros años de la década del 2000. Sin embargo, se dice que la organización del sector es inegalitaria y sus mecanismos

\footnotetext{
1 RUDEC/ IPSARD, Hanoi, Vietnam/ CIRAD-MOISA, Montpellier, France.

2 CIRAD, UMR SELMET, Montpellier, France.

3 CIRAD, UMR MOISA, Montpellier, France.
} 
de motivación no son suficicientes para asegurar el desarrollo de granjas pequeñas. Para evaluar los prospectos de las granjas pequeñas en el proceso de renovación de todo el sector lechero, llevamos a cabo un estudio en el distrito $\mathrm{Ba}-\mathrm{Vi}$, la región lechera más grande del delta del Río Rojo, que ha tenido una transición asombrosa: de producción concentrada y estatal, a granjas pequeñas. El estudio se enfoca en la gobernanza de la cadena de valor y en estrategias de renovación. La cadena de valor lechera local está dominada por granjas pequeñas y está caracterizada por relaciones contractuales entre recolectores de leche y procesadores industriales, semi-industriales y pequeños. La cadena local está ofrecida por un patrón de gobernanza relacional-captiva mezclada. La gobernanza relacional caracteriza los dos subcanales dentro de los cuales opera la industria a pequeña escala. La gobernanza captiva describe el papel principal de una compañía lechera que ha invertido en plantas de procesamiento de UHT y se ha beneficiado del apoyo del gobierno local. El importante papel de las autoridades locales y algunos desafíos de la renovación de cadenas se discuten.

Palabras clave: Sector lechero, gobernanza de cadena de valor, desarrollo de ganado, Vietnam

\section{摘要}

自21世纪初, 越南的乳制品行业已经历了迅速增长。然而, 该行业组织机构据说是不公平的, 其激励机制不足以确保小 农的发展。为评估小农在整个乳制品行业升级过程中的前 景，本文在红河三角洲最大的 “牛奶场区” (milkshed）巴维区一进行了一项研究。巴维牛奶场区经历了从国有集中 生产到小农生产这一巨大转变。研究聚焦于价值链治理和升 级策略。当地乳业价值链由小农主导, 其特征表现为私人收 奶员和产业、半产业、以及农舍加工商之间的合同关系。当 地链的特点则是, (其治理模式是一种) 由关系型和俘获 型共同存在的混合治理模式。关系型治理（Relational governance）是供小规模产业运作的两大子渠道的特点。俘获型治 理(captive governance)描述的是中型乳制品公司的主导角色, 这类公司拥有超高温加工设备，并从当地政府处获得支持。 本文探讨了公共权威的强有力作用以及价值链升级所面临的 挑战。

关键词: 乳制品行业, 价值链治理, 畜牧业发展, 越南 


\section{Introduction}

The economic reforms that began in Vietnam in $1986^{4}$ affected 1 agriculture and the whole agrofood sector through land allocation to individual farmers, liberalization of agricultural production, and the gradual privatization of state-owned enterprises (Dang 2009). The agricultural GDP grew annually by $4.2 \%$ and by $3.5 \%$ in the periods of 1986-2004 and 2005-2013 respectively. The livestock sector has been particularly dynamic with an annual growth of 5.3\% for the 2005-2013 period and, in 2014, represented $26.4 \%$ of agricultural GDP. Pig and poultry production accounted for $90 \%$ of livestock output (GSO 2014) ${ }^{5}$ while milk production has increased significantly, both in terms of the national dairy herd and of the average milk yield. The dairy herd quintupled from 41,241 to 227,020 cows between 2001 and 2014, mainly on smallholder farms. During the same period, milk production augmented from 64,703 to 549,533 tons (DLP 2014) Economic growth induced higher demand while enabling environment favored an increase in both milk production and consumption ${ }^{7}$. National policies were promulgated to encourage the dairy sector, such as the Decision $167^{8}$ supporting dairy development for the 2001-2010 period with a focus on smallholder production. In 2011, 90\% of all dairy cows were raised on small farms of less than 20 cows. Larger dairy farms were formed out of partially and progressively privatized state agro-forestry farms (FCV 2011).

Despite these improvements, the dairy industry only satisfies $30 \%$ of domestic demand (DLP 2014), and the remaining demand is covered by imported milk powder and dairy products worth US $\$ 1,097$ million in 2014 (Vietnam Custom 2015). The new livestock development policy $(2014)^{9}$ gives priority to the development of large commercial farms. While some authors report efforts by large dairy corporations to exclude small-scale vendors and family farms from value chains in developing countries (GRAIN 2011), others highlight the complementarity between firm-led governance and contracted smallholder farmers (Humphrey and Memodovic 2006).

This paper aims at characterizing the governance pattern of the local dairy value chain, and linking the governance to the economic performance and development of the chain. The respective roles of private firms and of government in value chain governance are explored to assess current upgrading trajectories and future prospects for smallholder dairy production.

4 The 'Đổi Mới' (Renovation) has moved Vietnam away from a centrally-planned economy to a "socialist-oriented market economy"

5 General Statistics Office

6 Department of Livestock Production (under the Ministry of Agriculture and Rural Development (MARD))

7 Per capita milk consumption increased from 3.7 liters in 1995 to 20 liters in 2013 (FaoStat, 2014)

8 Decision 167/2001/QD-TTg of the Prime Minister (26 $6^{\text {th }}$ October 2001)

9 MARD's Decision n'984/QD-BNN-CN (2014) approving the "Restructuration of the livestock sector towards improvement of added value and sustainable development" 


\section{Materials and Methods}

\section{Value chain governance and determinants of governance patterns: an integrated approach}

7 he emergence of governance in economics is linked to integra1 tion of international trade and disintegration of production (Feenstra 1998). As production is increasingly fragmented across geographical space and between firms, many studies focus on how these fragmentations are coordinated and exchanged (Gereffi et al. 2005). While some economists see market coordination in governance patterns, Humphrey and Schmitz (2000) refer to governance as any coordination of economic activities "through non-market relationships". This relates to various ways of steering activities that are embedded in value chains, not only networks but also more hierarchical forms. Between the two extremes of market and hierarchical governance, three governance modes are identified: "modular", "relational" and "captive" (Gereffi et al. 2005). In these three governance modes, lead firms exert their power by coordinating production visà-vis suppliers without direct ownership of the firms. In agribusiness value chains, such patterns include out-grower schemes, contract farming, category management by supermarket suppliers, marketing contracts, and farmer cooperatives (Humphrey and Memodovic 2006; Moustier 2010). These forms of coordination influence the costs of governance through their effects on the complexity of transactions, the codifi- ability of transactions, and the capabilities of the suppliers required for a specific transaction.

The global value chain approach (GVC) draws on Transaction Cost Economics (TCE) and Network theories, while focusing on the internal logics of sectors, such as industrial structure and production-process characteristics (Bair 2005). The TCE framework provides insights into the factors that determine value chain governance patterns by convening the effect of transaction characteristics (asset specificity, uncertainty and transaction frequency) and the associated transaction costs (both ex-ante and ex-post costs of contracting) (Williamson 1979). This approach argues that increases in uncertainty and the risks of opportunism result in greater use of complex contracts or vertical integration (Williamson 1991). Complementarily, Network theorists propound that problems as contractual hazards need to be managed at the inter-firm level through social mechanisms, i.e. trust, trustworthiness, reputation, norms, mutual dependence and information exchange (Powell 1989; Jones et al. 1997) that are called 'mundane' transaction costs (Gereffi et al. 2005). Institutional economists also suggest that such formal and informal institutions are "embedded" in their cultural and social environment. Hence, they underline historical processes and path-dependency by which specific institutional arrangements emerge in a given context (North 1990). Different forms of social embeddedness raised by network theory refer to the concept of 'proximity' which valorizes the re- 
sponse to market demand of arrangements and connections among actors engaged in the value chain (Moustier 2012). Recent literature highlights three levels of proximity: physical proximity (Gilly and Torre 2000), organizational proximity (Torre 2000), and functional proximity (Gereffi et al. 2005).

Governance arises when "some firms in the chain work to parameters set by others" (Humphrey 2005). A lead producer or a lead buyer play an important role in setting and enforcing parameters (product, process, logistic parameters) because they have a strong position in "core nodes" of the chain that allows them to extract different types of rents (Gereffi 2001; Humphrey and Schmitz 2002). The "captain" of the chain can be identified by key indicators: (i) share of chain sales, value added, and profits; (ii) relative rate of profit; (iii) share of chain buying power; (iv) control over key technology; (vi) holder of distinctive competence; and (vii) holder of chain "market identity" (brand-name) (Kaplinsky and Morris 2012).

The GVC framework, which has mostly been used for international chains, puts forward that increasing demand for quality and competition between firms translate into a shift from market to captive governance, driven by processing and retailing firms. From the literature on milk chains in emerging economies, it is hypothesized that milk chains tend to be steered by processing firms that place large-scale investments in processing and quality control, and develop contracts with farmers, those are provided with intermediate goods and technical assistance, in exchange of commitments to deliver milk. This has been evidenced in Brazil, Chile and Argentina (Reardon and Berdegué 2002); Bulgaria, Romania and Slovakia (Dries et al. 2009); India (Birthal et al. 2009). The governance of chains through contracts can be described as modular or captive depending on the asymmetry of power between suppliers and buyers and the strictness of contracts. In India, cooperatives facilitate farmers' access to services and markets, that somehow balances the power of industrial plants (Upadhyay and Ranjan 2007). In the quoted studies, contracted farmers benefit from higher profits and prices thanks to quality premiums. Public and private standards and services are described as complementary. In the paper, we consider if similar trends are observed in Vietnam through variables characterizing the governance (Table 1). We also assess the main economic results of the chain and ongoing upgrading strategies. Finally, our discussion of the role of public services contributes to the debate on livestock development policies.

\section{Study zone}

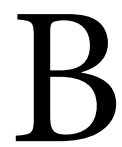

a-Vì district, located $60 \mathrm{~km}$ from Hanoi center, is the largest milkshed in the Red River Delta and includes a cluster of small farms that typically supply both regional and local markets (Hostiou et al. 2012). The dairy farms are mostly smallholding with fewer than 10 cows fed with less than 1 hectare of elephant grass, corn, or other 
Table 1: Variables to be analyzed in value chain governance

\begin{tabular}{|c|c|c|c|c|c|}
\hline \multirow{2}{*}{ Variables } & \multicolumn{5}{|c|}{ Governance pattern } \\
\hline & Market & Modular & Relational & Captive & Hierarchy \\
\hline $\begin{array}{l}\text { Term of the } \\
\text { relation }\end{array}$ & $\begin{array}{l}\text { Short-term } \\
\text { orientation }\end{array}$ & $\begin{array}{c}\text { Medium/ } \\
\text { Long -term } \\
\text { orientation }\end{array}$ & $\begin{array}{l}\text { Long-term } \\
\text { orientation }\end{array}$ & $\begin{array}{l}\text { Long-term } \\
\text { orientation }\end{array}$ & $\begin{array}{l}\text { Long-term } \\
\text { orientation }\end{array}$ \\
\hline $\begin{array}{l}\text { Information } \\
\text { exchange }\end{array}$ & Limited & Frequent & Frequent & $\begin{array}{l}\text { Frequent and } \\
\text { idiosyncratic }\end{array}$ & $\begin{array}{l}\text { Frequent and } \\
\text { idiosyncratic }\end{array}$ \\
\hline $\begin{array}{l}\text { Enforcement } \\
\text { mechanism }\end{array}$ & Price & $\begin{array}{l}\text { Standards } \\
\text { and } \\
\text { information }\end{array}$ & $\begin{array}{c}\text { Social } \\
\text { embeddedness }\end{array}$ & $\begin{array}{l}\text { Parameters } \\
\text { set by lead } \\
\text { firm }\end{array}$ & $\begin{array}{l}\text { Parameters } \\
\text { set by lead } \\
\text { firm }\end{array}$ \\
\hline $\begin{array}{l}\text { Dependence } \\
\text { level }\end{array}$ & Independent & $\begin{array}{c}\text { Inter- } \\
\text { dependent }\end{array}$ & $\begin{array}{c}\text { Inter- } \\
\text { dependent }\end{array}$ & $\begin{array}{c}\text { Inter- } \\
\text { dependent }\end{array}$ & Dependent \\
\hline $\begin{array}{l}\text { Power } \\
\text { asymmetry }\end{array}$ & No & Low & Low & High & High \\
\hline $\begin{array}{l}\text { Physical } \\
\text { proximity }\end{array}$ & Yes/No & Yes/No & Yes/No & Yes/No & Yes/No \\
\hline $\begin{array}{l}\text { Organizational } \\
\text { proximity }\end{array}$ & Yes/No & Yes/No & Yes & Yes/No & Yes/No \\
\hline $\begin{array}{l}\text { Functional } \\
\text { proximity }\end{array}$ & Yes/No & Yes/No & Yes/No & Yes/No & Yes \\
\hline $\begin{array}{l}\text { Captain of the } \\
\text { chain }\end{array}$ & $\begin{array}{c}\text { Upstream/ } \\
\text { Intermediate/ } \\
\text { Downstream/ } \\
\text { No captain }\end{array}$ & $\begin{array}{c}\text { Upstream/ } \\
\text { Intermediate/ } \\
\text { Downstream/ } \\
\text { No captain }\end{array}$ & $\begin{array}{c}\text { Upstream/ } \\
\text { Intermediate/ } \\
\text { Downstream/ } \\
\text { No captain }\end{array}$ & $\begin{array}{l}\text { Upstream/ } \\
\text { Intermediate/ } \\
\text { Downstream/ } \\
\text { No captain }\end{array}$ & Parent firm \\
\hline $\begin{array}{l}\text { Complexity of } \\
\text { transaction }\end{array}$ & Low & High & High & High & High \\
\hline $\begin{array}{l}\text { Codification of } \\
\text { information }\end{array}$ & High & High & Low & High & Low \\
\hline $\begin{array}{l}\text { Competence of } \\
\text { suppliers }\end{array}$ & High & High & High & Low & Low \\
\hline
\end{tabular}

Source: Authors' synthesis adapted from TCE, Network Theory and the CGV approach

forage. In 2014, the district dairy herd numbered 8,871 cows for a total milk production of nearly 30,000 tons (Figure 2). The development of smallholder dairying contributes to improved rural livelihoods through income generation, employment opportunities and better nutrition (Nguyen et al. 2013). However, the presence of industrial dairy processing companies, which have made well-targeted investments in the dairy chain, and cottage industry raises concerns about the effective and sustainable governance of the local value chain (Duteurtre et al. 2015). The roles of public services and private firms in sustaining transactions and linkages between actors are thus of particular attention in this paper. 
Figure 1: Map of study site

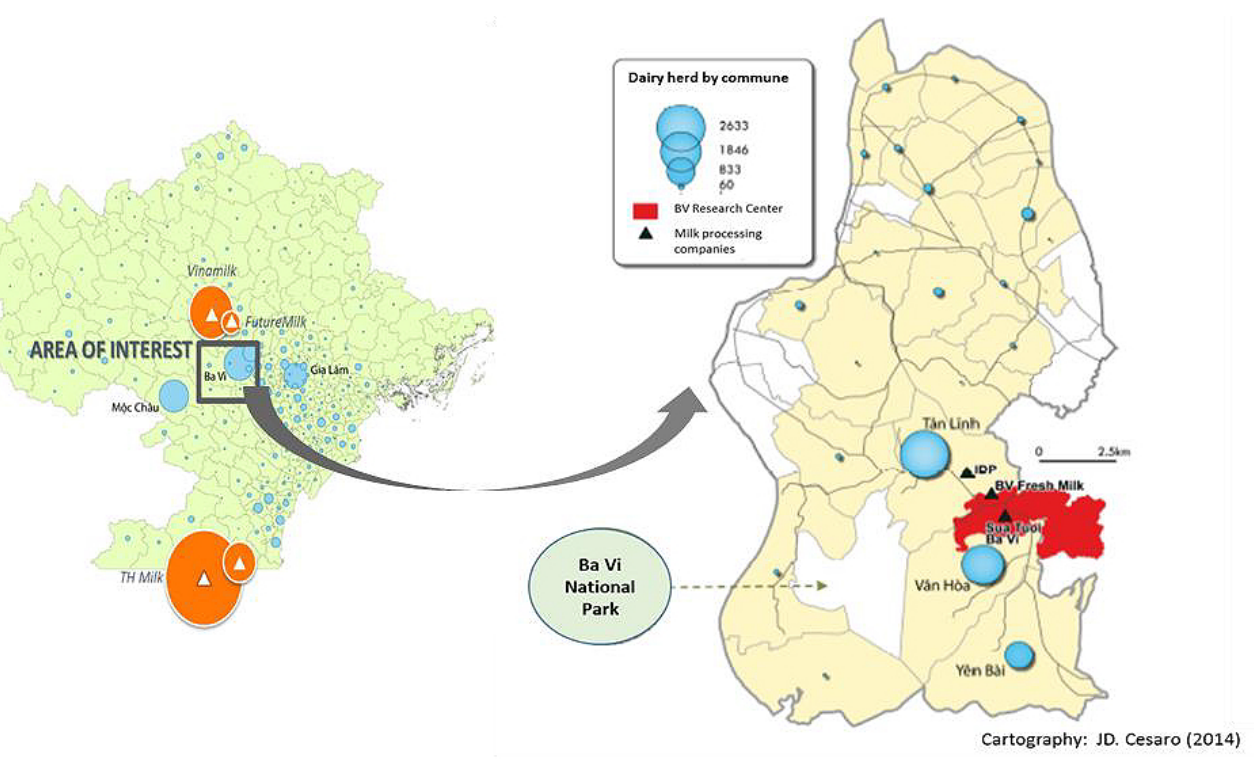

Figure 2: Increase in the dairy cow herd in Ba-Vi

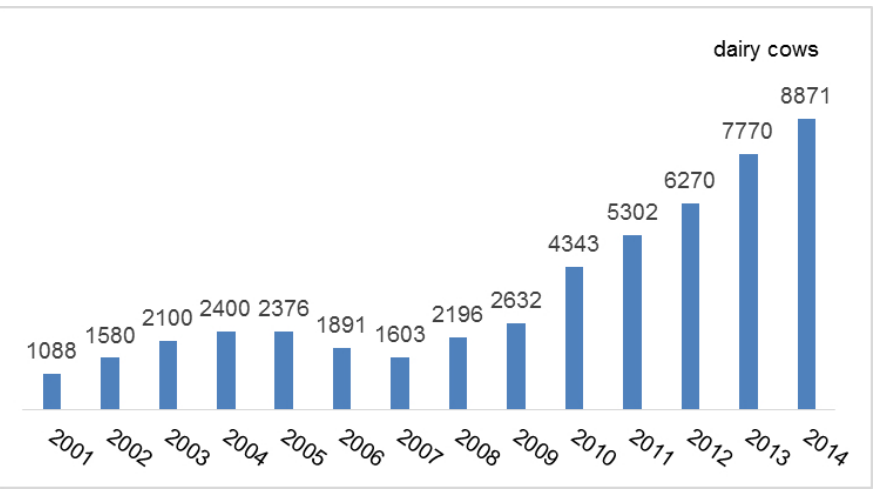

Source: Economic Division, Ba-Vì district, 2014

\section{Data and analysis}

7 he secondary data (socio-economic, agriculture, etc.) from the target district and communes were collected to picture the local dairy sector. We mapped the dairy channels using the value chain scoping exercise developed by ILRI (ILRI 2014) and focused on the three communes of Tản-Lĩnh, Vân-Hòa and Yên-Bài, which together represent $80 \%$ of the milk production in the district. Seventy people involved in dairy production and marketing in Ba-Vì were invited to focus-group discussions. Three main 
channels were identified corresponding to three types of processing: artisanal, small-scale, and large-scale.

An in-depth survey was sequenced in September 2014 (50 interviewees) and September 2015 (20 interviewees) comprising semi-structured interviews with different actors in the local chain (local authorities, 5 input and service suppliers, 21 producers, 9 collectors, 5 processors, 10 milk shops and 15 consumers) to characterize the value chain and scrutinize sustainability of the value chain. Given this small sample, the study should be considered as exploratory and the results have to be supported by a quantitative survey. Yet, some representativeness was sought in targeted interviewees according to their involvement in the three identified channels steered by the processors. Local actors were questioned about their business resources (assets, capital, know-how, labor, technology used), functions and activities (products purchased or sold, delivery and transport, services provided or received, access to credit, information exchange), economic results and management problems (prices of inputs and outputs, costs and margins, regulations, competition, strategy), relationship with other chain actors (contractual linkages, alliances, dependence, groups or associations, market relationships, information, power asymmetry, proximity), quality management (types of products, quality standards, payment schemes, quality labelling, certification), enabling environment and supports from local government (technical assistance, extension services, livestock insurance, etc.).
Possible changes over time of these variables were collected to grasp the dynamics of the whole system. Downstream flows from milk production to milk processing to end-use activities were traced to identify the drivers of innovations and who received the largest share of the margins and value addition produced by the chain.

\section{Results}

\section{The dairy development trajectory in $\mathrm{Ba}-\mathrm{Vi}$}

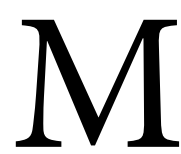

ilk production started in $\mathrm{Ba}$ Vì in the early $20^{\text {th }}$ century. The development trajectories of Ba-Vi's dairy sector correspond with the national trends in the periodized political economy (Figure 3): milk production concentrated on State farms (during the collectivism period), milk production on individual smallholder farms (during the Đổi Mới period) (Suzuki et al. 2006), and industrialization of the private dairy sector (since 2008) (Duteurtre et al. 2015).

The recent industrialization shift of the local dairy production has turned out since the Government launched its 2020 livestock development strategy in 2008. In the same year, the melamine crisis caused by adulterated powder milk imported from China hit the local chain as some local firms had to suspend their milk collection and to stop their processing activities. Among the processing companies involved in the collection of local milk, only International Dairy Products Joint-Stock Company (IDP) and Bavi Milk JSC. (BVM) 
What shapes the governance of the dairy value chain in Vietnam?

Insights from Ba-Vi milkshed (Hanoi)

Figure 3: Dairy production development trajectories in Ba-Vì

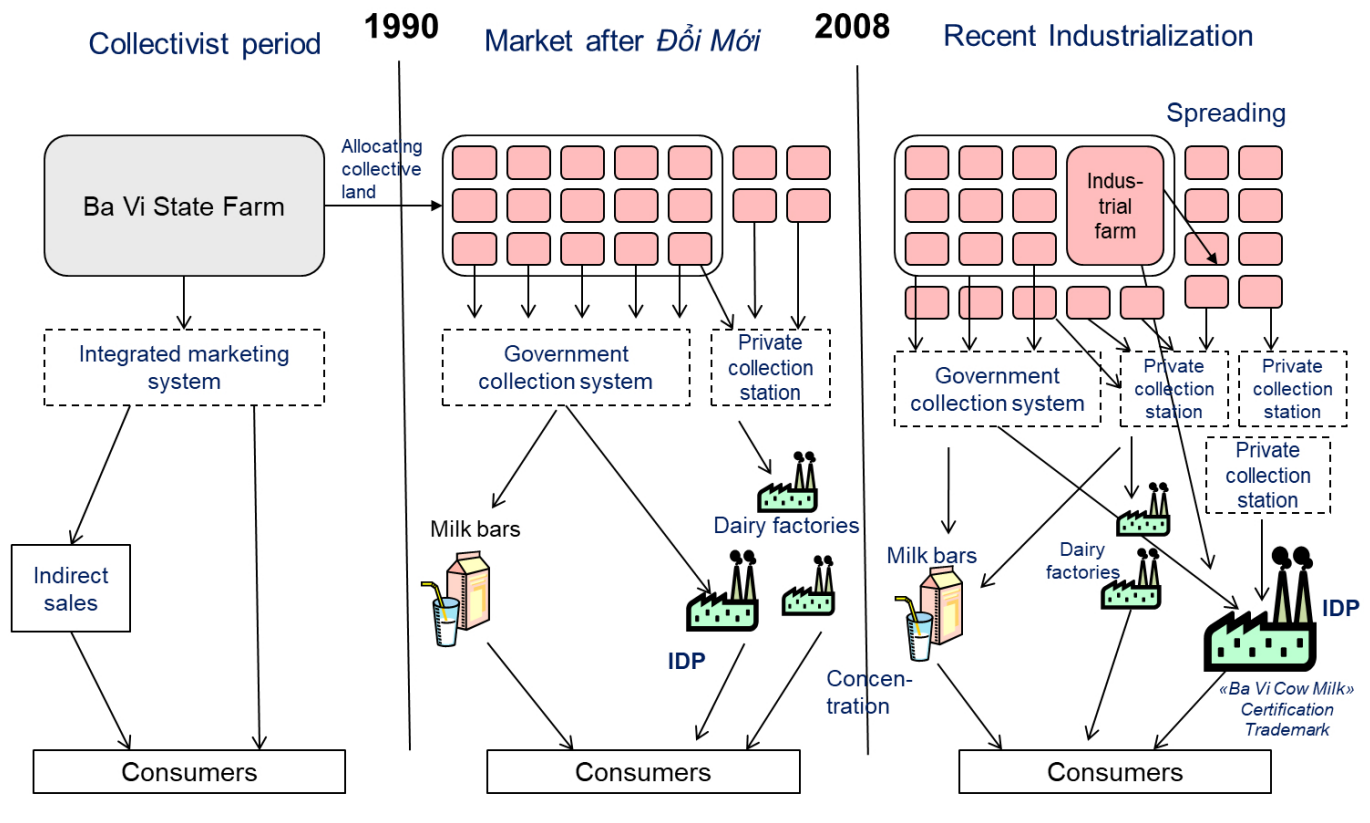

Source: Authors

continued to buy fresh milk from local farmers, resulting in a concentration of the dairy industry. IDP built a new dairy processing plant (2010) next to Ba-Vì Cattle and Forage Research Center ${ }^{10}$ (CFRC) in Tản-Lĩnh commune, and extended its collection network. These investments were further valorized and secured by a memorandum of understanding (MOU) between IDP and the district authorities. IDP then adopted a 2012-2020 dairy development program aiming at expanding local milk production through credit to farmers, improved breeding, new production techniques, supports for an industrial-scale "demonstration farm", and building an animal feed mill.

\section{Characterization of the $\mathrm{Ba}-\mathrm{Vi}$ dairy value chain}

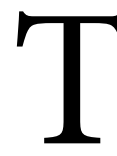

he Ba-Vi dairy value chain includes five segments: supply of inputs, milk production, milk collection, milk processing, and marketing and distribution of dairy products (Figure 4).

Input and service provision: Farmers have their inputs sourced from either self-supplied stock, mostly green fodder (representing about $50 \%$ of the farms' feed requirements), or external inputs purchased off-farm (industrial feed, artificial insemination, veterinary services, etc.). Beside the network of private veterinarians, local producers

10 In 1989, Ba-Vì State farm was converted to Cattle and Forage Research Center with mandates to conduct research into cow breeding and feeding, animal health and reproduction, and forage cultivation 
Figure 4: Ba-Vì dairy value chain

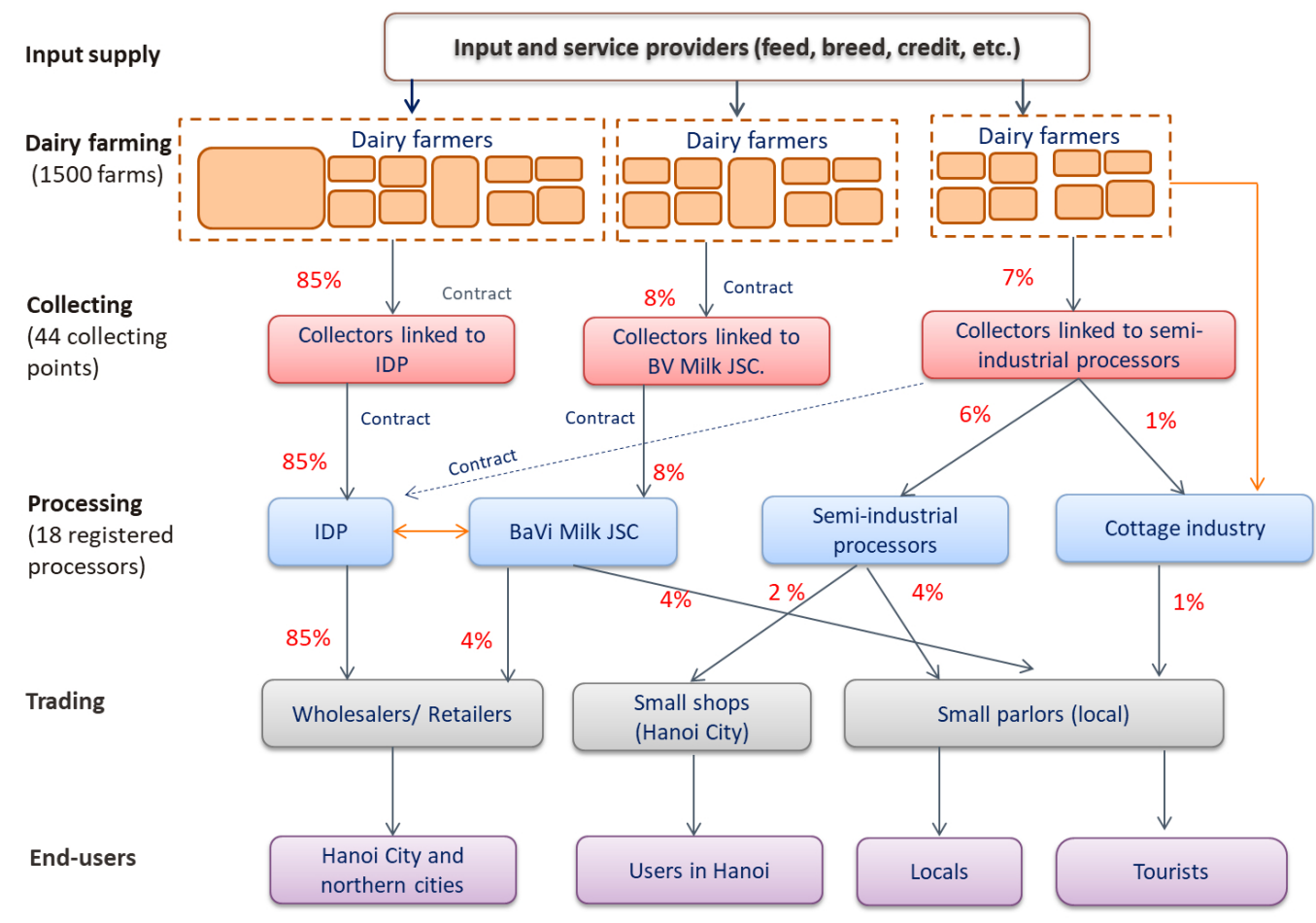

(Note: solid lines represent normative relationship; dash line illustrates non-regular relationship happening in winter when the surplus volume unabsorbed by semi-industrial processors (given their limited processing capacity) are sold to IDP)

Source: RUDEC's survey (Revalter, 2014-2015)

receive support from extension agents, who implement technical assistance programs launched by the local government and the Hanoi Livestock Development Center (HNLDC). The women's union, the farmers' association, and private collectors initiate and contract credits to producers with funds from the IDP, commercial banks and (in the case of the associations) their own members' savings.

Dairy farming: Milk production in $\mathrm{Ba}-\mathrm{Vi}$ is done on small farms of 0.51 hectare (Pham et al. 2011). Regarding feed availability, a "typical" family farm with three dairy cows has around $3000 \mathrm{~m}^{2}$ (around $60 \%$ of its cultivated land) under forage crops. Both farms diversified in crop-livestock production and farms specialized in milk production target stable markets based on contracts with industrial and semi-industrial processors. Some rely on verbal agreements with small-scale processors and cottage industry, who generally buy milk on a less strict quality at higher price but at a very limited volume.

Milk collection: Collectors are crucial middlemen who greatly contribute to the organization of local milk 
production and marketing. The collection of fresh milk anchors on annual contracts or verbal agreements with fixed prices, or spot market exchanges. Out of 44 local collection points, IDP has the largest network (32 stations) and buy up $85 \%$ of total district outputs. Most collection stations belong to private collectors who are supported by the companies for credit access and the provision of equipment and knowhow. All private collectors are part of the IDP milk payment scheme, which gives premium to high quality milk. The companies grade the milk delivered by producers through monthly quality analysis. The CFRC organizes its own collection network involving their contracted farmers ${ }^{11}$ and then sells the milk to IDP. Semi-industrial processors also rely on collection points where they buy $6 \%$ of all the fresh milk produced locally. Business relations between producers and semi-industrial processors stand on verbal agreements through those collection points. Most of the collection points are located along main roads to reduce time spent on transport from farms to the processing plants.

Processing: Eighteen registered milk processors operate in $\mathrm{Ba}-\mathrm{Vi}$. However, $93 \%$ of the milk is processed by two industrial processors (IDP and BVM) who produce a wide range of industrial products. IDP is the only processor to use the UHT technology. Around $6 \%$ of the milk is processed by semi-industrial processors (Ba-Vì Milk Cake - BVMC, Ất-Thảo, Xuân-Mai, etc.), the rest is processed by small cottage processors. The semi-industrial and small processing units produce pasteurized milk, milk cakes, caramel cream, and yoghurts.

Marketing and distribution of dairy products: Increasing income, rapid urbanization, changing diet habits have driven the increased milk consumption in Vietnam. The strong territorial identity of Ba-Vì (nature, tradition, culture, know-how) and quality label (certification trademark) spur the preference of consumers for Ba-Vì milk products. Industrialized products are sold by modern distribution (supermarkets, convenient stores) and shops mostly outside the district, particularly in Hanoi, whereas the semi-industrial and artisanal products are sold locally to tourists in small shops located along highways connecting Ba-Vì and Sơn-Tây town and to Ba-Vì national park.

Family farming is still secure thanks to major constraints on access to land and capital, which precludes the development of large industrial farms. Landless and labor-intensive milk production have allowed smallholders to stabilize their business and guarantee economic returns to family labor. Written contracts with milk collectors are underlined in controlling price fluctuations and enforcing contractual linkages between producers and processing companies.

11 CRFC's contracted farmers are those perform dairy activities based on rental leasing contracts. Some of their cows and all their land are leased from the CFRC. 


\section{The mixed governance pattern of the Ba-Vi dairy value chain}

Importance of product characteristics in the governance of the local value chain

Coupled with the functional characteristics of chain actors, the technical properties of the milk products affect inter-firm relationships and governance patterns. First, the perishability of raw milk and unsterilized dairy products localizes collecting and processing facilities close to production areas. This perishability restricts marketing flexibility for farmers and traders but increases their marketing risks. Marketing fresh milk products is thus characterized by physical proximity and contractual relationships, whereas sterilized products can be sold very far away through market adjustments. Second, seasonal variation in milk production and consumption raises concerns about the adjustment of milk collection, processing and storage, and more generally about balancing supply and demand. This seasonality creates trading risks for farmers, puzzles cost-efficient utilization of labor and processing facilities and com- plicates the structure of products for processors. IDP upgraded its processing line to diversify its products and to handle the abundance of raw milk in the off-season and contracted to purchase surplus milk from external collection points of semi-industrial processors and cottage industry. The UHT line installed in 2010, which manufactures storable dairy products, plays a significant role in this respect. Third, although milk is a relatively homogeneous product, its nutrient content varies considerably among producers, upon cow breed, feeding, and farm management practices. The heterogeneous quality requires significant investments and extra costs for grading, especially measuring the fat and dry matter content of the milk procured.

\section{Relational governance: linkage between dairy farmers and collectors}

The governance of the milk collection schemes is mainly relational. Linkages between farmers and collectors are defined by physical proximity, organizational proximity and functional proximity (Table 2).

\section{Table 2: Characterization of transactions determining proximity between farmers and collectors}

\begin{tabular}{ll}
\hline Type of proximity & Characteristics of transactions \\
\hline Physical proximity & Distance between farmers and collection points is less than $2 \mathrm{~km}$ \\
\hline $\begin{array}{l}\text { Organizational } \\
\text { proximity }\end{array}$ & $\begin{array}{l}\text { Family relationships between producers and collectors } \\
\text { Moral factors that shape mutual confidence }\end{array}$ \\
\hline Functional proximity & $\begin{array}{l}\text { Agreed sharing of collection areas between collectors (and } \\
\text { processors) }\end{array}$ \\
\hline
\end{tabular}


Besides the proximity of collecting points and milk producers, processing facilities have been built in the district to ensure just-in-time processing. Collection points of industrial processors are installed along the main roads to enable access by big tank trucks, whereas the collection points of semi-industrial processors settle farther away. While most of dairy farmers deliver their milk to the collection points within their village, some farmers fetch milk to collection points of another village because of social connections. The social proximity reduces uncertainties related to price, quality, and quantity while enables access to informal credit, information, and knowledge.

Collectors bridge farmers and companies through formal contracts. The bilateral contracts between farmers and processors refer to the collector's name and are signed at collector's place. As the collector is responsible for managing and enforcing the contracts, actors consider those contracts as "tri-party" agreements. Beside terms regulating rights and responsibilities of farmers and processors, the contract defines different tasks performed by the collector (delivering milk to the factory, sampling milk for quality test, proceeding payments, etc.). However, the one-year term implies contractual ties not being the only institution to ensure the regularity of milk delivery and the loyalty of the producers. There is always a risk that a farmer will switch from one collector to another when the contract ends. Thus, financial and moral aspects as well as interpersonal proximity enforce the contract. Trust between farmers and collectors is sustained by other supports: credit at low interest rates to farmers to buy cows or to build facilities (VND 20-50 million $^{12}$ for a term of 6 to 12 months with extension possibility), or advances (VND 1-3 million) for the purchase of feed, which farmers can reimburse in milk. Since farmers find it difficult to access to formal credit provided by banks (due to the high interest rate, absence of mortgages or collateral assets such as Red Book ${ }^{13}$ ), financial support from collectors has largely contributed to the local dairy development. Connections between collectors and farmers hang on social principles and on events taking place in the villages and communes (weddings, funerals, house-warming, religious events, etc.). Milk collectors strengthen their relationship with farmers by buying milk of lower quality rejected by the processors (in this case, milk is bought at a lower price for feeding young calves), delivering veterinary services free of charge, providing technical assistance and information or giving bonuses for milk delivered. These incentives are regarded as tools for collectors' transactional assurance and improving milk quality (Saenger et al. 2013). Other attributes of relational governance are evidenced by frequent information exchanges between dairy farmers and milk collectors. Any changes in the policy or strategy of processing compa-

12 Equivalent: US\$1,000-US\$2,500

13 "Red Book" is the Land Use Right Certificate delivered by local administration 
nies, or price fluctuations are passed to farmers by collectors. Milk collectors are obliged to invest their time and resources in building such networks, but they themselves benefit from relational governance in two ways: (i) it enables them to expand their input business (feed, animal medication); (ii) they are able to obtain necessary information to reduce risks connected with milk quality at farm level. The above-mentioned legal and social mechanism facilitates the symmetric relationship between dairy producers and collectors.

\section{Captive governance: outstanding role of IDP as lead firm}

Different from the informal link between farmers and cottage industry, mixed connection between farmers and semi-industrial processors, the relationship between farmers and IDP is formal. Facilitated by the MOU with the district authority (2009), IDP has a quasi-monopoly in purchasing local milk as IDP collects $85 \%$ of the milk locally produced and imposes purchase prices and the quality norms (dry matter content, fat content, antibiotics, etc.) that are a reference for the whole district. Semi-industrial processors organize their collection and price their purchases based on the price range defined by IDP. Both the pricing and the payment system (penalty, bonus, and quality standard) are decided by IDP without formal discussions with the farmers, who are in a weak position in the chain. Dairy farmers are not organized to benefit from collective actions, and are thus unable to exert power or negotiate the milk prices and other concerns. Dairy farmer groups are established in only three out of seventeen dairy farming communes. Except for technical training classes and visits to farmers, these groups don't have any collective activities (as bulk purchase of inputs) or action plan to dialogue and negotiate with the processors.

IDP drives the technological advances in local industry by investing in UHT technology. This investment allows IDP to produce pasteurized longlife milk, which helps balance supply and demand in winter, and target larger markets outside the district (i.e. Hanoi city and even Central and Southern provinces). Moreover, IDP has built up professional teams for the different stages (collection, processing and sale) to provide technical assistance to their farmers and collectors. Besides, IDP commits short-term and medium-term credit to the farmers linked to their network. While formal bank loans usually require collateral, informal loans and microfinance enable dairy farmers to purchase cows or make other investments.

IDP officializes its operations by contractual relationships with producers and private collectors aiming at securing supplies and reducing risks. The written contract system has been in use since IDP's debut in the region. Today, most local producers have a contractual link with a processor (large or small, industrial or semi-industrial), although a small number of producers supply their milk to cottage industry 
without written contracts. Under the teria. The penalty and bonus policy is contract terms, together with techni- also defined by quality attributes. IDP cal aspects, hygiene requirements, and encourages farmers to produce quality respecting sanitary norms, IDP agrees milk by offering premiums tied to the to buy all milk that meets quality cri- milk quality and quantity. Other bo-

Table 3: Specifications of governance patterns in the local dairy value chain

\begin{tabular}{|c|c|c|}
\hline Variables & Relational Governance & Captive Governance \\
\hline Term of relation & Long-term orientation & Long-term orientation \\
\hline $\begin{array}{l}\text { Information } \\
\text { exchange }\end{array}$ & $\begin{array}{l}\text { Frequent information ex- } \\
\text { change between producers and } \\
\text { collectors (at collecting points, } \\
\text { social events, etc.) }\end{array}$ & $\begin{array}{l}\text { The connection between dairy } \\
\text { farmers and processing compa- } \\
\text { nies is created and maintained } \\
\text { by a network of collectors }\end{array}$ \\
\hline $\begin{array}{l}\text { Enforcement } \\
\text { mechanism }\end{array}$ & $\begin{array}{l}\text { Social relations between dairy } \\
\text { farmers and collectors are } \\
\text { driven by relational linkage, } \\
\text { mutual trust }\end{array}$ & $\begin{array}{l}\text { The terms and conditions in the } \\
\text { contract between dairy farmers } \\
\text { and processing companies con- } \\
\text { cern the milk that is purchased } \\
\text { and processed }\end{array}$ \\
\hline $\begin{array}{l}\text { Dependence } \\
\text { level }\end{array}$ & $\begin{array}{l}\text { Inter-dependence of farmers } \\
\text { and collectors }\end{array}$ & $\begin{array}{l}\text { Inter-dependence of collectors } \\
\text { and processors (processing com- } \\
\text { panies) }\end{array}$ \\
\hline $\begin{array}{l}\text { Power } \\
\text { asymmetry }\end{array}$ & $\begin{array}{l}\text { Relatively balanced/symmetric } \\
\text { partnership between farmers } \\
\text { and collectors }\end{array}$ & $\begin{array}{l}\text { Farmers are highly dependent on } \\
\text { processing companies who de- } \\
\text { cide on the required milk quality } \\
\text { and purchase price. }\end{array}$ \\
\hline $\begin{array}{l}\text { Captain of the } \\
\text { chain }\end{array}$ & IDP & IDP \\
\hline $\begin{array}{l}\text { Complexity of } \\
\text { the transaction }\end{array}$ & $\begin{array}{l}\text { Tri-party milk procurement } \\
\text { contract }\end{array}$ & $\begin{array}{l}\text { Tri-party milk procurement con- } \\
\text { tract }\end{array}$ \\
\hline $\begin{array}{l}\text { Codification of } \\
\text { information }\end{array}$ & $\begin{array}{l}\text { Norms and standards to en- } \\
\text { sure the quality of milk to be } \\
\text { collected and processed }\end{array}$ & $\begin{array}{l}\text { Norms and standards to ensure } \\
\text { the quality of milk to be collect- } \\
\text { ed and processed } \\
\text { Certification trademarks are } \\
\text { granted to } 2 \text { local processors } \\
\text { (IDP and BVM) }\end{array}$ \\
\hline $\begin{array}{l}\text { Competences of } \\
\text { suppliers }\end{array}$ & $\begin{array}{l}\text { Improvement in technical } \\
\text { knowledge and economic sit- } \\
\text { uation thanks to training and } \\
\text { credit }\end{array}$ & $\begin{array}{l}\text { Improvement in technical } \\
\text { knowledge and economic sit- } \\
\text { uation thanks to training and } \\
\text { credit }\end{array}$ \\
\hline
\end{tabular}


nuses are awarded for respecting the code of practice (certified by IDP), use of tanks and equipment for transporting milk, and compliance with farm sanitary standards. A stable year-round purchase price discourages farmers from switching to another processor. Although the prices set by IDP are somewhat lower than cottage industry on spot market, farmers appreciate selling to IDP because of regular milk purchase during year. Along with the quality-based payment, IDP frequently monitors compliance of its contracted farmers with hygienic and farming practices. Captive governance led by IDP, on the one hand, has contributed to the rapid adoption of the Code of practice at the farm level and, in turn, to the company's success in creating a stable source of raw material for its large-scale processing. On the other hand, under this governance pattern, by founding a decentralized collection network, IDP aims at reducing its transaction costs (particularly search, screening and transfer costs) since third-party collectors take over coordinating exchanges with small farmers. Yet, the costs of monitoring and enforcing the contracts with dairy farmers, in particular supervision of husbandry practices and control of milk quality, are still relatively high since most local producers are smallholders spreading out over a large area.

The milk chain is therefore characterized by a two-facet governance (Table 3): relational governance between farmers and collectors, and captive governance between farmers and IDP, the industrial processing firm.

Figure 5: Distribution of profit and added value among actors in the dairy value chain

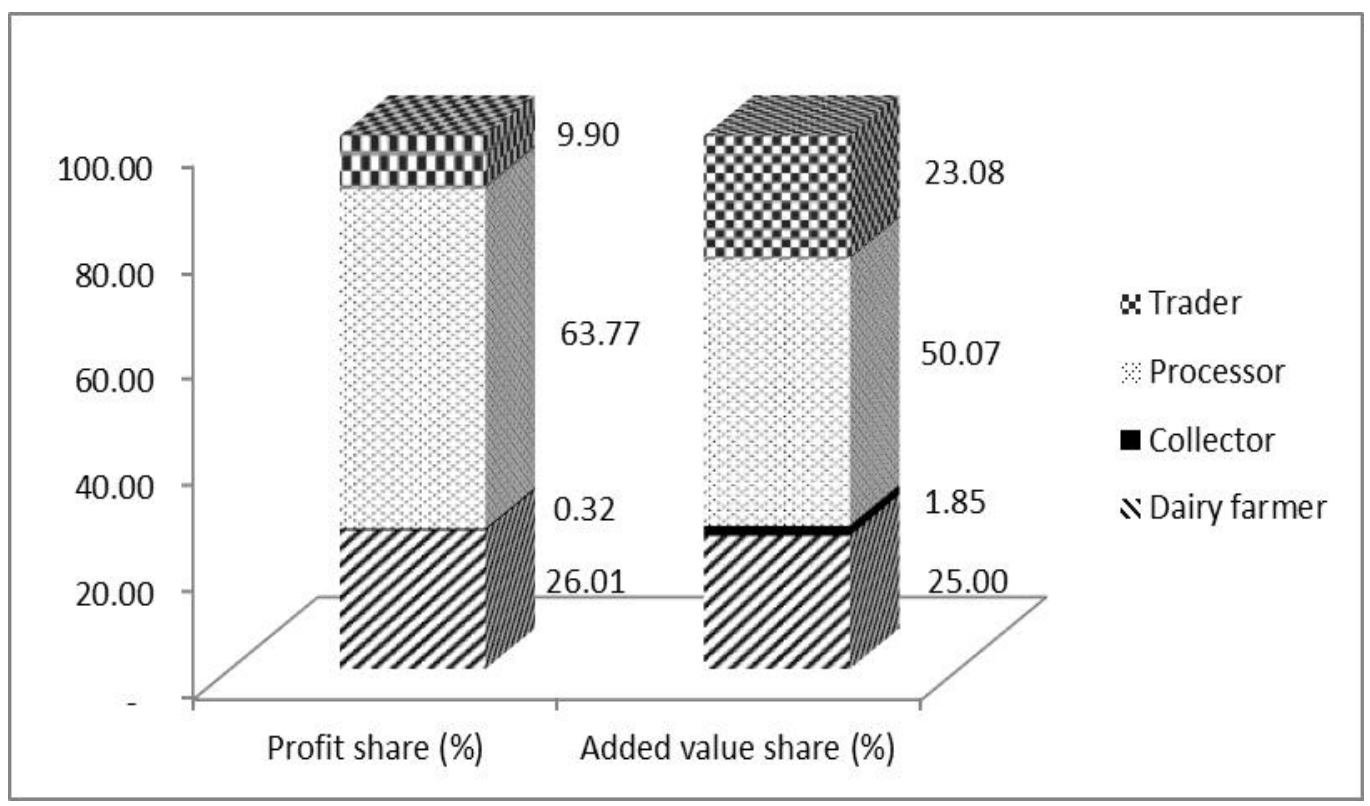

Source: RUDEC's survey (Revalter, 2014-2015) 


\section{Economic performance of the value chain}

$\mathrm{E}$ conomic returns for chain stakeholders reflect chain operations and forms of governance. The unequal distribution of the profit and value added highlights the supremacy of processors, especially IDP, in the local dairy chain (Figure 5). IDP takes the largest share $(63.77 \%)$ of the profit, whereas farmers receive less than one-third (26.01\%) of the total profit made in the chain, which is disproportionate with respect to their investment costs (which account for up to $50 \%$ expenses of the chain as a whole). The dairy value chain is a typical chain in which the processors lead the chain forward, and the majority of added value of the chain is subsequently captured by processors like IDP. This asymmetric distribution has weakened the bargaining power of the dairy farmers. It is prevailing that all investments made by the processors (even small) are counted in their production costs and value addition. On the contrary, family labor, self-supply of grass for feed, and opportunity costs are neglected in earnings obtained by the farmers. If all costs were included, the added value gained by dairy farmers in the chain would be significantly lower. This unequal distribution proves the captive governance led by IDP, but raises concerns about the sustainable development of the dairy sector in general and of the dairy chain in Ba-Vì in particular.
Enabling environment: the role of public services in value chain governance

$\mathrm{F}$ ollowing the National Dairy Development Plan (2001), a number of research and scientific efforts were made in the dairy sector with the participation of international development actors. CFRC strengthened its research activities through government funds and international research and development (R\&D) projects (JICA-funded dairy projects, Vietnam-Belgium Dairy project, the establishment of Moncada frozen semen centre, etc.). The international $\mathrm{R} \& \mathrm{D}$ projects built capacity for the local farmers and collectors as well as empowered the CFRC and contributed to transform its role from production development to the scientific research and technical consulting.

The dairy production in $\mathrm{Ba}-\mathrm{Vì}$ is high on the agenda of Hanoi's rural and agricultural development strategy. Many actions have been done to support all the chain actors. CFRC land was allocated to former state farm workers to raise dairy cows. A long-term land lease was granted to IDP for its investment in the large-scale farm and processing plant. Technical assistance has been provided through extension programs delivered by CFRC, HNLDC, and IDP to farmers (concerning farming practices such as animal care, feeding, heat-stress control, etc.). Around 100 training courses were provided to 7,000 farmers between 2000 and 2014. Furthermore, the local government also cares genuinely for the territorial identity of Ba-Vì milk by 
applying for certification mark "Ba-Vi cow milk", in 2009, as intellectual property rights protection. The district government's control over the certification mark aims at maintaining the quality and reputation of $\mathrm{Ba}-\mathrm{Vì}$ milk; but reserving the mark rights for only two companies (IDP and BVM) may prevent other companies who are qualified from obtaining the certification mark and, to some extent, ensures IDP's monopoly on collecting milk locally as IDP and BVM have partially merged.

Since 2012, the district dairy development strategy appears to be closely linked with the IDP development plan. Beyond the use of certification mark, the district government supports IDP in many institutionalized operations in the 5-year MOU. Together with the government's favorable policies (agricultural insurance for producers ${ }^{14}$, favorable loans and taxation regimes, etc.), the district administration controls the entrance of other dairy companies by gauging daily collection capacity of minimum $600 \mathrm{~kg}$ for placing collection points. This structural mechanism endeavors to a stable supply of milk to IDP and BVM.

\section{Discussion and Conclusion}

\section{Structural transformation and organization of the value chain}

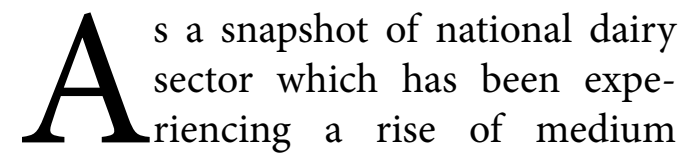

and large farms, Ba-Vì district, in the 2010-2014 period, witnessed a relevant change in farm size: decreasing number of small farms of $1-5$ cows (from $89.55 \%$ to $61.17 \%$ ), and increase in number of farms of more than 5 cows (farms of 6-9 cows: from $8.14 \%$ to $32.17 \%$; farms of more than 9 cows: from $2.31 \%$ to $6.66 \%)$. Priority is given to the medium and large farms in view of higher economic returns, better epidemic and quality control and improved effluence management.

Despite the rapid structural changes in parts of the sector, smallholders till dominate dairy production. Low entry barriers to production are set by both dairy processors and local government to ensure smallholder farmers access to credit, public services (extension and veterinary services), and training as well as improved infrastructure. Higher barriers concern land constraints, dependence on concentrates, demanding quality standards and permanent contracts with companies. Smallholder production shows more resilient against market fluctuations, but it is difficult to generate sufficient volume to meet increasing demand and face higher competition from imported milk products. Accordingly, a niche marketing seems to be an important opportunity that help Ba-Vì milk overcome barriers to trade (special demand for fresh milk, quality local product, local market for tourists, restaurants, etc.). Increasing domestic demand and improved roads would facilitate sale

14 The State provides grants to cover the insurance fees: $100 \%$ of insurance fees for poor farmers, $80 \%$ for quasi-poor farmers, $60 \%$ for non-poor farmers, and $20 \%$ for cooperative groups (who are part of a pilot project on livestock insurance). 
of the products in the urban markets. Besides, technology is highlighted in transforming the chain and shaping the value chain governance (crossbred cows, new technology, and market dynamics such as prices).

\section{Governance structure and upgrading strategy}

The governance of the value chain relies on very complex social networks including dairy producers, collectors, processors, and public authorities, and resulting from long historical processes. Informal relations play a crucial role alongside formal contracts in this regulation (Culas and Pannier 2014). Although IDP makes contracts with farmers and defines quality standards and prices (which are attributed to captive governance), collectors are a key node between farmers and IDP, and the link between farmers and collectors is embraced by relational governance. Captive governance emerges in relation with large-scale investments by IDP and quality management objectives. Despite IDP's attempts to introduce strong vertical coordination of the local chain, private collectors have been able to maintain their position and keep some power in their relations with dairy farmers. Like dairy production in Son-La province, Ba-Vì dairy farmers suffer from a very weak professional organization, meaning they have very little bargaining power to negotiate the prices dictated by IDP (Bui et al. 2013; Nguyen et al. 2013). Hence, captive governance is parallel with chain upgrading, but it translates into an asymmetric sharing of incomes. Yet our data is lacking to assess whether contracted farmers earn more or less income than non-contracted ones, in particular through coercive measures on quality.

The investments made by IDP have had a major impact on the upgrading trajectory of the local value chain. Among the upgrading dimensions, vertical integration and upgrading of both processes and products appear to be the most significant changes. The capacity of IDP to invest in farmers' development projects and in UHT processing technology has provided new opportunities and value addition for farmers and for other small-scale processors, through improved processing and packaging. The future of processing firms may depend on their capacity to set up contracts with appropriate incentives. The role of the authorities in managing the Ba-Vì certification trademark and milk quality control will certainly affect success chances of semi-industrial processing plants in the future.

While the problems of melanine contamination in China are linked to the rapid and unregulated development of the sector (Pei et al. 2011), a weak cooperation of firms in the Vietnamese fast-growing dairy sector has led to new challenges and compromised the ability of the value chain to maintain the viable link among actors and food safety. The different forms of local collective organizations (the processor federation initiated by IDP, BVM and BVMC in 2013 to guarantee the quality of local dairy products, to 
protect the interest of those concerns and to reduce risks; association of 14 collectors in Tản-Lĩnh commune established in 2013 aiming at mutual aid, strengthened solidarity, and limited competition among collectors) have no operational protocol to undertake their mission in reality. Meanwhile, the dairy farmer groups cannot perform collective actions. A national dairy management board encompassing different stakeholder representatives (producers, processors, state and consumers) is recommended to improve coordination between local actors and to handle all emerging issues and conflicts of the value chain.

\section{Value chain governance and territory governance}

A

s Vinamilk, the biggest milk company in Vietnam, IDP and BVM rely on large supply network of smallholder farmers and intermediary collectors within a milkshed where milk is collected into a tank mixing milk from different producers. Bimonthly payment to farmers for delivered milk bases on the quality test done by the companies, while collectors receive a collection fee. The current decentralized collection system is beneficial to processors by reducing their investment, but is argued unfair and untransparent by both farmers and collectors since milk tests are done at the dairy plants and they have to accept the results and prices published by the companies. Such quality and payment system crystalize the tensions between farmers and processors; thus, an inde- pendent quality test agency is crucial in stabilizing the dairy zone.

Dairy smallholders in $\mathrm{Ba}-\mathrm{Vi}$, like in other milksheds in Vietnam and other countries in the South, are facing challenges related to strengthened health regulations and increasing resource competition among operators that weakens the participation of small producers in the market. Innovations in the dairy industry, such as conception of new products manufactured in the territory (cheese for example), will allow small producers and processors to have easier market access, to diversify their products and to increase their revenues. This would also help to meet other issues such as addressing seasonal fluctuations of milk products, lower costs to food, or the improvement of the quality of milk.

The recent strategy for eco-tourism development of Hanoi to 20202030 opens opportunities and challenges to the sustainable development of the dairy chain. From economic perspective, a fashion trend would be to create more diversity in dairy products and tours integrated with homestay at and visit to dairy farms. Community eco-tourism contributes to higher income for the locals. From social perspective, with a strong territorial identity, the local chain should involve more the local farmers and artisanal and small processors. From environmental perspective, for the non-grazing dairy system characterized by the confinement of animals, attention should be paid to effluence management and sustainable development of the territory. 
The current certification trademark has contributed to the higher price of the local milk in the market. However, the upgrading to protected geographical indication (PGI) would be strategic in view of a stronger quality label as an integral attribute to the sustainability of the products in the market. Plus, PGI strategy will further valorize local natural resources, local know-how and the proactive participation of territorial organizations and actors to the sustainable and inclusive development

\section{Institutional framework and enabling environment}

$\mathrm{R}_{\mathrm{in}}^{\mathrm{cos}}$ eardon et al. (2012) argued that the dynamics of the food chain in Asia is driven by economic development and public actions. Public services contribute to the upgrading and modernization of the value chain. The MOU between IDP and district government (2009) and the processing plant built by IDP on the land of CFRC are outstanding examples of public-private partnership in the agri-food sector. The Livestock Restructuring Plan (2014) converges with the Livestock Development Strategy (2008) in orienting the focus of dairy production in traditional regions, including Ba-Vì. Apart from controlling imports of milk powder and milk prices, the support provided by the State (technical assistance, credit, and building infrastructure) incentivizes dairy production, improves market connections and promotes market integration. At the provincial and district levels, strong local government involvement is apparent in economic, technical, organizational and other angles. However, the definition of quality is not shared by all the actors in the chain.

Dairy industry, as a component of livestock sector is proved to be negatively affected by increasing international integration, notably TPP (VERP 2015). Import of livestock and livestock products, especially dairy products, from countries of comparative advantages (New Zealand, United States) is on rise. From the perspective of consumers and importers, the dairy market becomes more competitive after tariff removals, but it uncertainly could help domestic prices fall. While dairy (processed) products will suffer more from acute competition of imported products, raw milk can take advantage of natural trade barriers (i.e. perishability of fresh milk). Competition pressure mainly comes from powder milk. Short-term impact is not really clear, but to ensure the long run, it is necessary to push sector restructuring to raise quality and competitiveness (dairy zoning, feed crop production, control over imported powder milk). Vietnamese dairy enterprises have to invest into modern and advanced technology and sustain their market shares. Additionally, given imprecise packaging regulations and insufficient quality control as institutional bottlenecks (Pedregal and Nguyen 2009), it requires transparency in defining fresh milk, publicizing information of milk products to protect benefits consumers and businesses. Moreover, the prices of milk products must be under good control to ensure 
the access of consumers to products of quality and of reasonable prices and to encourage enterprises to invest in milk production rather than being dependent on imports

\section{Policy implications}

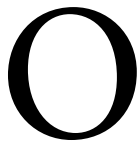

ur analysis highlights the role played by private companies and government intervention in promoting the dairy sector in $\mathrm{Ba}-\mathrm{Vi}$, which has emerged recently and undergone a rapid transition. The context of the local dairy industry led to the emergence of three factors that influence transaction costs and hence shape a "mixed" type of governance needed to facilitate transactions along the local dairy chain. The three factors are (i) the structure of the local dairy value chain, which is driven by private industrial-scale processing companies; (ii) specific agricultural characteristics, and (iii) strong backstop of public services. Strong state involvement has taken different forms but is responsible for the initial impulses to the local dairy sector. Entry barriers to production and trade have increased significantly over time. The State uses the barriers by partnering with private firms to facilitate the flows of products and information. Smallholder dairy farmers still have a role in local economy in the context of land constraint and livelihood assurance, but further support is needed to ensure their access to stable markets and help them understand quality and food safety regulations through training, improved support services and protection of intellectual property rights. These measures should be combined with specific regulations aimed at preventing or reducing potential negative effects (exclusion of small producers and processors, environmental degradation, unfair distribution of added value, market competition, etc.). Unilateral decision making by the "captain" of the chain should be replaced by new rules of the game co-constructed with all the actors to ensure a sustainable and inclusive value chain.

Acknowledgement: The authors thank the ANR and AIRD for financing the Revalter project (Multi-scale assessment of livestock development pathways in Vietnam)

\section{References}

Bair, Jennifer. 2005. "Global Capitalism and Commodity Chains: Looking Back, Going Forward." Competition \& Change 9 (2): 153-80.

Birthal, P. S., A. K. Jha, M. M. Tiongco, and C. Narrod. 2009. "Farm-Level Impacts of Vertical Coordination of the Food Supply Chain: Evidence from Contract Farming of Milk in India." Indian Journal of Agricultural Economics 64 (3): 481-96.

Bui, Thi Nga, Huu Cuong Tran, and Phillipe Lebailly. 2013. "An Analysis of the Value Chain of Fresh Milk in the North of Vietnam: The Case-Study in Son La Province." Vietnam's Socio-Economic Development Review 68: 272-86. 
Culas, Christian, and Emmanuel Pannier. 2014. "Etude de rapports sociaux et des échanges entre les différents acteurs impliqués dans la fillière a Ba Vi." REVALTER No 3. Hanoi: CNRS.

Dang, Kim Son. 2009. Agriculture, Farmers and Rural Development in Vietnam: Present and Future. The Gioi Publishing House. Hanoi.

DLP. 2014. "Scheme for Restructuring of Livestock Sector toward Promoted Added Value and Sustainable Development." Department of Livestock Production of Vietnam.

Dries, Liesbeth, Etleva Germenji, Nivelin Noev, and Johan F. M. Swinnen. 2009. "Farmers, Vertical Coordination, and the Restructuring of Dairy Supply Chains in Central and Eastern Europe." World Development, Agrifood Industry Transformation and Small Farmers in Developing Countries, 37 (11): 1742-58.

Duteurtre, Guillaume, Duy Khanh Pham, and Jean-Daniel Cesaro. 2015. "Le Bassin laitier de Bavi (Vietnam): Un territoire délevage façonné par les politiques publiques, entre logiques industrielles et soutien à la paysannerie." In Voies lactées: Dynamique des bassins laitiers entre globalization et territorialisation, Napoléone M., Corniaux C., Leclerc B.(coords.), 67-87. Cardère éditeur.

FCV. 2011. "Dairy Farming in Vietnam: Dairy Development Program." Slides presented at the Friesland Campina Vietnam, Binh Duong.
Feenstra, Robert C. 1998. "Integration of Trade and Disintegration of Production in the Global Economy." The Journal of Economic Perspectives 12 (4): 31-50.

Gereffi, Gary. 2001. "Shifting Governance Structures in Global Commodity Chains, With Special Reference to the Internet." American Behavioral Scientist -AMER BEHAV SCI 44 (10): 1616-37.

Gereffi, Gary, John Humphrey, and Timothy Sturgeon. 2005. "The Governance of Global Value Chains." Review of International Political Economy 12 (1): 78-104.

Gilly, Jean-Pierre, and André Torre, eds. 2000. Dynamiques de Proximité. Paris: L'Harmattan.

GRAIN. 2011. "The Great Milk Robbery: How Cooperations Are Stealing Livelihoods and a Vital Source of $\mathrm{Nu}-$ trition from the Poor." Madrid.

GSO. 2014. Statistical Year Book 2013. Vol. 2013. Statistical Year Book. Hanoi: Statistical Publishing House.

Hostiou, Nathalie, Pham Duy Khanh, Guillaume Duteurtre, Vu Trong Binh, and Benoit Dedieu. 2012. "Relationships between Work Organisation and Size of Dairy Farms: A Case Study Based in Vietnam." Tropical Animal Health and Production 44 (7): 170916.

Humphrey, John. 2005. "Shaping Value Chains for Development: Global Value 
Chains in Agribusiness." Project Report. GTZ Trade Program.

Humphrey, John, and Olga Memodovic. 2006. "Global Value Chains in the Agrifood Sector." Working paper. Vienna: UNIDO.

Humphrey, John, and Hubert Schmitz. 2000. "Governance and Upgrading: Linking Industrial Cluster and Global Value Chain Research." Working paper IDS 120. The Interaction of Global and Local Governance: Implications for Industrial Upgrading. Brington: Institute of Development Studies.

- - . 2002. "How Does Insertion in Global Value Chains Affect Upgrading in Industrial Clusters?" Regional Studies 36 (9): 1017-27.

ILRI. 2014. "Value Chain Assessment Toolkit." CGIAR Livestock and Fish Research Program. http://livestock-fish. wikispaces.com/VC_Toolkit.

Jones, Candace, William S. Hesterly, and Stephen P. Borgatti. 1997. "A General Theory of Network Governance: Exchange Conditions and Social Mechanisms." The Academy of Management Review 22 (4): 911-45.

Kaplinsky, Raphael, and M. Morris. 2012. A Handbook for Value Chain Research. Brington: Institute of Development Studies, University of Sussex.

Moustier, Paule. 2010. "Commodity Chains, Supply Chains and Value Chains." Markets and agriculture linkages for cities in Asia.

- - - 2012. "Organisation et performance des filières alimentaires dans les pays du Sud: le rôle de la proximité." Synthèse des travaux pour l'habilitation à diriger des recherches. Serice Recherche. Montpellier: CIRAD-UMR MOISA.

Nguyen, Hung Anh, Huu Cuong Tran, and Thi Nga Bui. 2013. "Production and Marketing Constraints of Dairy Farmers in Son La Milk Value Chain, Vietnam." Greener Journal of Business and Management Business Studies 3 (1): 031-037.

North, Doughlass C. 1990. Institutions, Institutional Change and Economic Performance. Cambridge; New York: Cambridge University Press.

Pedregal, Virginie Diaz, and Ngoc Luan Nguyen. 2009. "Is Fresh Milk Powdered Milk? The Controversy over Packaged Milk in Vietnam." In The Crisis of Food Brand: Sustaining Safe, Innovative and Competitive Food Supply, 65-85. Gower Publishing Ltd.

Pei, Xiaofang, Annuradha Tandon, Anton Alldrick, Liana Giorgi, Wei Huang, and Ruijia Yang. 2011. "The China Melamine Milk Scandal and Its Implications for Food Safety Regulation." Food Policy 36 (3): 412-20.

Pham, Duy Khanh, Natalie Hostiou, Benoit Dedieu, Trong Binh $\mathrm{Vu}$, and Guillaume Duteurtre. 2011. "Caractérisation de La Diversité Des Exploita- 
tions Laitières Au Vietnam: Implication Méthodologique Pour La Mise En Place D’un Réseau D’observation Des Élevages." Poster presented at the Journee 3R - 2011, Paris.

Powell, Walter W. 1989. "Neither Market nor Hierarchy: Network Forms of Organization / W.W. Powell." Research in Organizational Behavior 12:295-336.

Reardon, Thomas, and Julio Berdegué. 2002. "The Rapid Rise of Supermarkets in Latin America: Challenges and Opportunities for Development." Development Policy Review, Special Issue: Supermarkets and agrifood systems: Latin American challenges, 20 (4): 371-88.

Reardon, Thomas, Chen Kevin Z., Minten Bart, and Adriano Lourdes. 2012. "The Quiet Revolution in Staple Food Value Chains: Enter the Dragon, the Elephant, and the Tiger." IFPRI books. International Food Policy Research Institute (IFPRI).

Saenger, Christoph, Matin Qaim, Maximo Torero, and Angelino Viceisza. 2013. "Contract Farming and Smallholder Incentives to Produce High Quality: Experimental Evidence from the Vietnamese Dairy Sector." Agricultural Economics 44 (3): 297-308.

Suzuki, K., M. Kanameda, S. Tachibana, T. Ogawa, T. T. S. Dang, and D. U. Pfeiffer. 2006. “Temporal Dynamics of Dairy Health and Production in Rural Smallholder Communities in Northern Vietnam." Tropical Animal Health and Production 38 (5): 415-29.
Torre, André. 2000. "Economie de La Proximité et Activité Agricoles et Agro-Alimentaires." Revue d'Economie Resgionale et Urban 3 (This paper is an attempt by apply the research program of the economics of proximity to the study of the dynamics of the agricultural and agri-business sectors.): 407-27.

Upadhyay, K.K., and Raghwesh Ranjan. 2007. "Case Study 1: Milk Supply (in India)." In Regoverning Markets: A Place for Small-Scale Producers in Modern Agrifood Chains, Bill Vorley, Andrew Fearne and Derek Ray, 137-42. England: Gower Publishing.

VERP. 2015. The Impacts of TPP and AEC on the Vietnamese Economy: Macroeconomic Aspects and the Livestock Sector. The Gioi Publishing House.

Vietnam Custom. 2015. Custom Handbook on International Merchandise Trade Statistics of Vietnam 2014. Financial Publishing House.

Williamson, Oliver E. 1979. “Transaction-Cost Economics: The Governance of Contractual Relations." Journal of Law and Economics 22 (2): 233-61.

-_-. 1991. "Comparative Economic Organization: The Analysis of Discrete Structural Alternatives." Administrative Science Quarterly 36 (2): 269-96. 